\title{
Special Issue
}

\section{Reconstruction: Key to Social Responsibility Risk Assessment for Tourism Investment Projects ${ }^{\dagger}$}

\author{
Chen $\mathrm{Lv}^{1,2}$, Xiaoyan $\mathrm{Li}^{2}, *(\mathbb{D})$ \\ ${ }^{1}$ China Tourism Academy, Room 319, Block 2, Guanghua Chang'an Building 7 Jianguomennei Ave., Dongcheng District, Beijing 100005, China

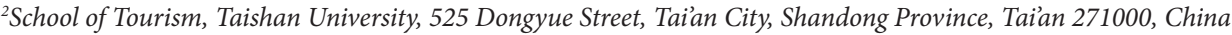

\section{ARTICLE INFO}

\section{Article History}

Received 16 September 2020

Accepted 07 January 2021

Keywords

Tourism investment social responsibility risk reconstruction

\begin{abstract}
The strategy of investing large-scale tourism projects abroad has become one of the most important strategies for China to help developing countries to improve their people's livelihood, provide assistance and practice China's international responsibility. The proposal and implementation of the Belt and Road Initiative (B\&R for short) provides an opportunity for the rapid development of China's large-scale tourism investment project abroad. Current research on investment risks mainly focuses on economic ones, while social responsibility risk is far less discussed. There are even fewer risk studies based on the International Organization for Standardization (ISO) 26000 Guidance on Social Responsibility, not to mention a systematic evaluation and quantitative analysis of social responsibility risk of $\mathrm{B} \& \mathrm{R}$ large-scale tourism investment project abroad. Based on the six core subjects and 35 issues listed in ISO 26000 Guidance on Social Responsibility, with the method of the analytic hierarchy process, this paper fixes and sorts the evaluation indexes of social responsibility risk, so as to reconstruct the assessment for social responsibility risk of large-scale tourism investment project abroad. This assessment consists of three first-level value dimensions, nine second-level value dimensions and 21 third-level value dimensions. The results show: in the social responsibility risk assessment for $\mathrm{B} \& \mathrm{R}$ large-scale tourism projects abroad, stress should be put not only on project implementation and project selection, but also on project follow-up management. Among the 21 third-level dimensions, top 10 dominant indexes are listed in turn as follows: dispute treatment, 0.0727 , community environment 0.0610 , education and awareness 0.0529 , community participation 0.0499 , skills and technology 0.0426 , union organizations 0.0193 , vulnerable groups 0.0168 , respect for property rights 0.0163 , ecological restoration 0.0160 , and work environment condition 0.0156 .
\end{abstract}

(C) 2021 The Authors. Published by Atlantis Press B.V. This is an open access article distributed under the CC BY-NC 4.0 license (http://creativecommons.org/licenses/by-nc/4.0/).

\section{INTRODUCTION}

Large-scale tourism investment abroad refers to the economic behavior of undertaking large-scale tourism investment projects abroad under the guidance of the host country or region government, with foreign tourism enterprise group as the main body. Characterized by large investment scale, long cycle and complex social influence, it has important use function and great social significance. In recent years, Chinese enterprises have invested more than $\$ 100$ billion in 10 large-scale tourism projects abroad. The strategy of investing large-scale tourism projects abroad has become one of China's important strategies to help developing countries improve their people's livelihood, provide assistance and fulfill its international responsibilities [1]. The proposal and implementation of the Belt and Road (B\&R) Initiative provides an opportunity for the rapid development of China's large-scale tourism investment project abroad. In 2017, Dalian Wanda Group invested as much as $\$ 10$ billion in Malaysia’s Dama City tourism investment project and India's Haryana Industrial City project.

*Corresponding author. Email: 348566634@qq.com

'Supported by: Social science planning project of Shandong Province (Digital Shandong special project) (20CSDJ62); China Postdoctoral Science Foundation Project (2017M620958)
In Paris, China invested more than 3 billion euros in a large-scale cultural tourism project. However, the loss rate is as high as $90 \%$ and the losses run into hundreds of billions of dollars. The $\$ 3.6$ billion Bahamas resort project conducted by China State Construction Engineering Group Co. Ltd., which would have been completed in 2015, went bankrupt due to labor issues. A 180-milliondollar project in Cancun, Mexico, went bankrupt in 2014 as a result of environmental problems of mangroves and the protection of bird homes. These failures make the complex problem of risks of Chinese large-scale investment project abroad once again a hot topic and a global challenge theoretically and practically.

Current research on investment risks mainly focuses on the economic ones, while social responsibility risk is far less discussed. Domestic evaluation of social responsibility risk is mainly based on the perspective of enterprises rather than the B\&R largescale tourism investment abroad. There are even fewer systematic and quantitative analysis studies of social responsibility risk of $B \& R$ large-scale tourism investment project abroad based on International Organization for Standardization (ISO) 26000. According to the six core subjects of ISO 26000, human rights, labor practices, the environment, fair operating practices, consumer issues and community involvement and development, combined with the background of the $\mathrm{B} \& \mathrm{R}$ and the current national conditions of China, this paper 
develops and innovates the social responsibility risk assessment of B\&R large-scale tourism investment project abroad by identifying the essential dimensions to lower investment risks and sorting the key dimensions so as to promote the sustainable development of $\mathrm{B} \& \mathrm{R}$ large-scale tourism investment project abroad.

\section{DIMENSIONS OF SOCIAL RESPONSIBILITY RISK ASSESSMENT}

\subsection{The Connotation and Evaluation of Social Responsibility Risk Assessment}

Risk generally refers to the uncertainty that is inconsistent with the expected goal, including the uncertainty of the occurrence of events, the uncertainty of losses, as well as the uncertainty of both occurrence possibility and loss degree. Social responsibility risk of investment projects refers to the uncertainty of the future investment income due to the failure to fulfill the social responsibility during the implementation process and the follow-up management of the investment project. Investors may take the risk of income loss, or even the loss of principal, which is mainly manifested as natural risk, social risk, economic risk, technical risk, humanistic risk and cultural risk, etc. (Table 1).

\subsection{Dimensions of Social Responsibility Risk Assessment}

Ghosh and Jintanapakanont [2] applied the method of factor analysis to identify key risk factors in engineering projects. Huseby and Skogen [3] incorporated decision-making behavior uncertainty into the risk evaluation indexes of investment projects. Jiang et al. [4] adopted the method of fuzzy clustering and fuzzy similarity to evaluate the risks of investment projects. Irene Hall et al. [5] studied the impact of 3215 emergencies on investment projects in the United States from 1990 to 1992. Malone et al. [6] considered shared dependency, flow dependency, co-dependency and the interdependence among them as the dominant factors of complex risks of investment project. According to the fuzzy set theory, Knight and Fayek [7], Lee and Daniel [8], Lin and Chen [9], Sadiq and Husain [10], Motawa et al. [11], incorporated cost risk, safety risk, bidding risk, environmental risk and project change risk into investment project evaluation. Su and Wang [12] pointed out the influence of environment on investment decisions. Jia [13] insisted that top-level decision of the government have a great impact on investment projects. Han et al. [14], Zhou and Ren [15], Huang and

Table 1 Connotation of investment risks

\begin{tabular}{lc}
\hline Perspectives & Experts and scholars \\
\hline $\begin{array}{l}\text { Uncertainty of occurrence } \\
\text { of events }\end{array}$ & Willett (1901), Mowbray (1995), \\
Uncertainty of loss & Williams (1985), Knight (2003) \\
& Rosenb (1972a and b), Haynes \\
Possibility of occurrence and & (1985) \\
loss degree & Williams (1993), Tumer (1992), \\
\hline
\end{tabular}

Source: According to the relevant data collation.
Tang [16] believed that social responsibility affected the direction of investment projects. Meng et al. [17], Zheng [18], Lin [19], Wang et al. [20], Zhou and Yu (2005) [21], Hong and Li [22], Hu et al. [23], Zhou and Wang [24] etc. regarded energy consumption, local residents' demands, carbon emissions, performance, emergency and income inequality as the key dominant factors of investment projects. Feng and Zhang [25] designed the risk assessment indexes of agricultural investment projects from the perspectives of external environmental risks, technological risks and internal risks of enterprises. Li [26] used the balanced scorecard method to design the index system of complex risk assessment of engineering projects. The above experts and scholars mainly conducted research from the perspective of economic risks.

In terms of social responsibility risk, Sun et al. [27] conducted the research from the point of institutional quality, green innovation and energy efficiency and energy policy (Table 2). Sun et al. [28] studied the environmental sustainability performance of South Asia. Yang and Chen (2020) [29], Lv and Ge (2020) [30], studied social responsibility risks of investment abroad from the perspectives of lacking environmental awareness, improper handling of labor relations, conflicts with local residents, and the environment. Zhang et al. (2016) [31], analyzed the risks faced by Chinese investment in foreign infrastructure projects based on the environment of the host country, complexity of infrastructure projects and stakeholders. Li (2016) [32] analyzed the risk of foreign investment from five dimensions of politics, management, culture, law and nature. $\mathrm{Pu}$ (2015) [33] analyzed the risks of Chinese railway enterprises' foreign investment projects from the perspectives of politics, economy and society. Yang and Pi (2019) [34] believed that China's Outward Foreign Direct Investment faced risks of politics, terrorism, nationalism, policies and laws, exchange rate, cultural conflicts and other aspects. Other scholars and enterprises have studied China's foreign large-scale investment projects, including social responsibility risks of some large-scale tourism investment projects from different perspectives, such as, Huang (2011) [35] and Wang (2013) [36], from the perspective of respects for human rights, Feng (2005) [37] and Wang (2005) [38] from the point of consumers' issues, Wanhua Group, Shan Dong province, from the angle of fair operating practices, and He (1995) [39], Zhao (2005) [40], Jiang (2009) [41], and Zhang (2013) [42] etc. from the point of environmental protection. However, in terms of social responsibility risks, the above researches are carried out only from a certain aspect or angle without a systematic research based on any international standards of social responsibility, let alone a social responsibility risk assessment for the B\&R large-scale tourism investment projects abroad. Therefore, based on the standards of ISO 26000, the six core subjects, namely human rights, labor practice, environment, fair operation practice, consumer issues, community and development are incorporated as the dimensions of social responsibility risk assessment of the $B \& R$ large-scale tourism investment projects abroad.

\section{ISO 26000 GUIDANCE ON SOCIAL RESPONSIBILITY}

The standard of ISO 26000 Guidance on Social Responsibility is the first relatively unified international social responsibility standard in the world. Since the 1990s, the concept of social responsibility has 
Table 2 Typical social responsibility assessment dimensions

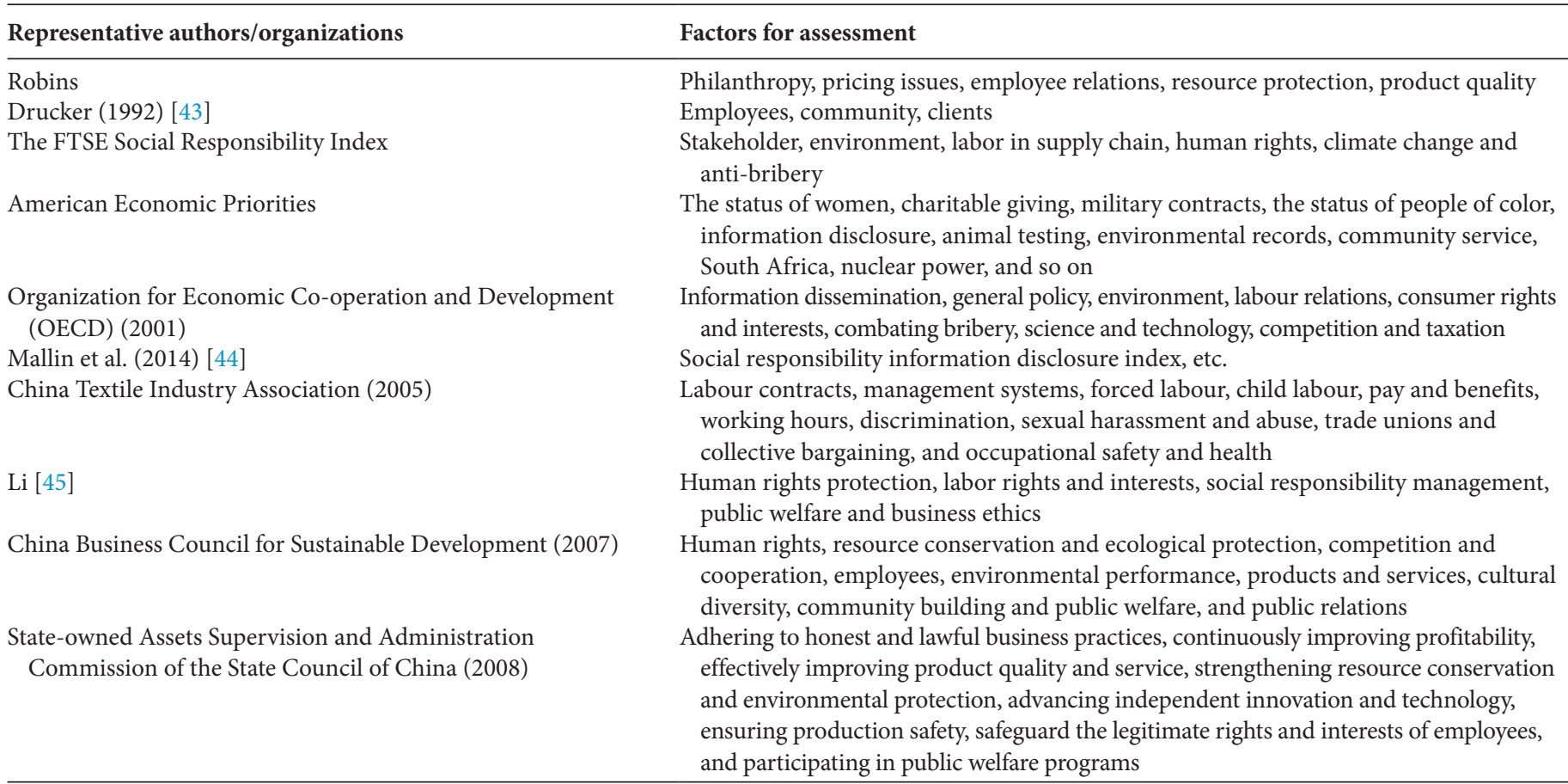

Source: According to the relevant data collation.

set off a great wave and pushed the development of global social responsibility movement. At first, only corporate social responsibility for enterprises was proposed, namely, the production regulations of enterprises. The International Labor Organization is committed to promoting international labor standard; based on 10 Principals of Global Compact, the United States established the United Nations Global Compact Office and the Social Accountability International; in 1997, the American civil society organization issued the social responsibility standard of thirdparty certification (SA8000), Guide to Sustainable Development Reporting (latest version G3) and global reporting initiative, etc. (see Table 3). However, all the above standards and guidance target narrowly and have certain limitations. How to uniformly define social responsibility, especially how to practice and measure social responsibility has become a common research subject for the international community. At the request of the committee on consumer policy, ISO 26000, an international social responsibility standard, was developed by the Technical Management Bureau and the plan of ISO 26000 project was carried out in 2005. After 5 years' formulation and having reached a consensus between developed and developing countries and among various stakeholders involving more than 90 countries and more than 40 international and regional organizations for social responsibility, ISO 26000 Guidance on Social Responsibility was officially promulgated by the ISO on November 1, 2010 (see Table 4 for details).

As a key definition of ISO 26000, social responsibility is defined as "responsibility of an organization for the impact of its decisions and activities on society and the environment, through transparent and ethical behaviour that contributes to sustainable development, including health and the welfare of society, takes into account the expectations of stakeholders, is in compliance with applicable law and international norms of behavior, and is integrated throughout the organization and practised in its relationships." ISO 26000 mainly focuses on organizational governance and involves six core subjects and 35 issues (see Table 5 for details).

\section{SOCIAL RESPONSIBILITY RISK ASSESSMENT AND POSITIONING OF B\&R LARGE-SCALE TOURISM INVESTMENT PROJECT ABROAD}

\subsection{The Hierarchy Model of Social Responsibility Risk Assessment}

Theoretically speaking, the construction of an evaluation index system should be carried out from three levels: overall design, application operation and a clear goal. Similarly, the principles for constructing a comprehensive evaluation index system for social responsibility risks should also be considered from these three aspects. While the overall design of the assessment is supposed to be scientific, systematic, comprehensive and complete, and reasonably reflect the social responsibilities of the investment project from all aspects, the indicators selected in every level the system need to be measurable, attainable and comparable, so as to facilitate the application and operation of indicators in assessment. In addition, the indicator system should be future-oriented, sustainable and forward-looking, in order to guide the improvement of the sustainable development capacity of investment projects.

Due to geopolitics, the host country's political environment and monopoly of Chinese large tourism investment project abroad, 
Table 3 Representative international norms of social responsibility

\begin{tabular}{|c|c|c|}
\hline Norms & Countries using the standard & Contents \\
\hline SO14000 (1996) & $\begin{array}{l}\text { More than } 130 \text { countries and regions use it, thus } \\
\text { making it a recognized standard for global } \\
\text { quality and environmental management systems }\end{array}$ & $\begin{array}{l}17 \text { elements involving environmental policy, } \\
\text { planning, fact and operation, inspection and } \\
\text { corrective measures and management review }\end{array}$ \\
\hline SA8000 (1997) & $\begin{array}{l}2919 \text { organizations covering } 65 \text { industries of } \\
62 \text { countries; Top ten countries and regions of } \\
\text { certification: India, China, Italy, Brazil, Pakistan, } \\
\text { Vietnam, Spain, Romania, Taiwan China, } \\
\text { Philippines }\end{array}$ & $\begin{array}{l}\text { Child labour, health and safety, forced labour, } \\
\text { discrimination, freedom of association and the } \\
\text { right to collective bargaining, remuneration, } \\
\text { disciplinary measures, management systems and } \\
\text { working hours }\end{array}$ \\
\hline UN Global Compact (1999) & $\begin{array}{l}\text { With } 8700 \text { businesses in more than } 130 \text { countries, } \\
\text { it is the world's largest voluntary social } \\
\text { responsibility initiative }\end{array}$ & $\begin{array}{l}10 \text { principles of global consensus in the fields } \\
\text { of human rights, labour, environment and } \\
\text { anti-corruption }\end{array}$ \\
\hline $\begin{array}{l}\text { OECD Guidelines for Transnational } \\
\text { Corporations (2000) }\end{array}$ & $\begin{array}{l}\text { Signed up by } 34 \text { governments, and gradually } \\
\text { promoted globally }\end{array}$ & $\begin{array}{l}\text { General policy, information disclosure, labour } \\
\text { relations, environment, fight against bribery, } \\
\text { consumer interests, science and technology, } \\
\text { competition and taxation, etc. }\end{array}$ \\
\hline $\begin{array}{l}\text { Global Reporting Initiative } \\
\text { (GRI) (2000) }\end{array}$ & $\begin{array}{l}\text { By November 2014, 20,881 GRI reports had } \\
\text { been released }\end{array}$ & $\begin{array}{l}\text { Beyond environment, it expands the reporting } \\
\text { framework to society, environment, economy } \\
\text { and governance areas }\end{array}$ \\
\hline
\end{tabular}

Source: According to the relevant data collation.

Table 4 Formulating process of ISO 26000 Guidance on Social Responsibility

\begin{tabular}{lll}
\hline Stages & Time & Contents \\
\hline Stage 1 & 2001 & $\begin{array}{l}\text { An ISO subordinate, Consumer Policy Committee (COPOLCO) submitted an application to the council. The application was } \\
\text { approved and a Strategic Advisory Group was established. } \\
\text { COPOLCO presented a feasibility report on the standardization of social responsibility to the International Organization for } \\
\text { Standardization (ISO) Council. }\end{array}$ \\
Stage 2 & 2002 & $\begin{array}{l}\text { ISO set up a special strategy advisory group to develop social responsibility standards. } \\
\text { Technical Management Bureau (TMB) of ISO decided to launch the project of ISO 26000 Guidance on Social Responsibility. } \\
\text { ISO 26000 Guidance on Social Responsibility working group was established, and they held the first meeting. The development } \\
\text { of ISO 26000 Guidance on Social Responsibility was officially initiated. } \\
\text { The expert group submitted the ISO 26000 project proposal and draft to the Committee of Social Responsibility, and the } \\
\text { committee draft was formed after a second discussion. } \\
\text { The draft was amended by the countries and stakeholders involved in the formulation of ISO 26000, and the draft of international } \\
\text { standard was confirmed, only to be approved. } \\
\text { ISO 26000 Guidance on Social Responsibility Standards were officially released. }\end{array}$ \\
2008 & 2010 &
\end{tabular}

Source: According to the relevant data collation.

there are huge social responsibility risks in investing abroad. China Railway Construction's bid for a high-speed rail line in Mexico and Cosco Group's bid for a 67\% stake in Greece's Piraeus Port failed due to the factional conflicts and regime change in Mexico and Greek. The reason why Japan has relatively fewer social responsibility risks in large investment projects abroad is that Japanese enterprises carry out international cooperation with developed countries or host countries of the investment. Zhang et al. (2014) [46] studied the influence of host behavior on social responsibility risk of China's large investment projects abroad, and the results showed that geopolitics and political environment of the host country is one of the main factors for the social responsibility risk of China's investment. Therefore, this paper incorporates international cooperation and joint development, domestic political risks and geopolitical environment of the host country into the indexes of social responsibility risks of the B\&R large-scale tourism investment projects abroad. What is more, according to the 21 thirdlevel dimension indicators extracted from the six core subjects and 35 issues listed in ISO 26000, this paper constructs three first-level indicators including project selection, project implementation and project follow-up management. Therein, project selection consists of international collaborative development, domestic political environment and regional political environment of the host country. Human rights, labor practice, environment and fair operation practice are included in project implementation, and consumer issues, community involvement and development included in project follow-up management. Therefore, the hierarchy model of social responsibility risk assessment for the $\mathrm{B} \& \mathrm{R}$ large-scale tourism investment project abroad is constructed with three firstlevel value dimensions, nine second-level value dimensions and 21 third-level value dimensions.

\subsection{Weight and Consistency Test of Social Responsibility Risk Indicators}

\subsubsection{Weight measurement and consistency test of stratified target in decision-making target}

According to the characteristics and evaluation requirements of social responsibility risk assessment of the B\&R large-scale tourism investment projects abroad, this paper adopts the 
Table 5 ISO 26000 Guidance on Social Responsibility

\begin{tabular}{|c|c|c|}
\hline Core subjects & Issues & Dimensions extracted in this paper \\
\hline \multirow[t]{8}{*}{ Human rights $\mathrm{A}_{21}$} & Due diligence & \multirow[t]{2}{*}{ Due diligence $\mathrm{A}_{211}$} \\
\hline & Human rights risk situations & \\
\hline & Avoidance of complicity & \multirow[t]{2}{*}{ Handling of complaints $A_{212}$} \\
\hline & Resolving grievances & \\
\hline & Discrimination and vulnerable groups & \multirow[t]{2}{*}{ Vulnerable groups $\mathrm{A}_{213}$} \\
\hline & Civil and political rights & \\
\hline & Economic, social and cultural rights & \multirow{2}{*}{ Economic, social and cultural rights $\mathrm{A}_{214}$} \\
\hline & Fundamental principles and rights at work & \\
\hline \multirow[t]{4}{*}{ Labour practices $\mathrm{A}_{22}$} & $\begin{array}{l}\text { Employment and employment relationships } \\
\text { Social dialogue }\end{array}$ & Employment and employment relationships $\mathrm{A}_{221}$ \\
\hline & Conditions of work and social protection & \multirow{2}{*}{ Conditions of work and social protection $\mathrm{A}_{222}$} \\
\hline & Health and safety at work & \\
\hline & Human development and training in the workplace & Human development and training in the workplace $\mathrm{A}_{223}$ \\
\hline \multirow{4}{*}{ The environment $A_{23}$} & Prevention of pollution & Prevention of pollution $A_{231}$ \\
\hline & Sustainable resource use & Sustainable resource use $\mathrm{A}_{232}$ \\
\hline & Climate change mitigation and adaptation & Global warming $\mathrm{A}_{233}$ \\
\hline & $\begin{array}{l}\text { Protection of the environment, biodiversity and } \\
\text { restoration of natural habitats }\end{array}$ & Ecological restoration $\mathrm{A}_{234}$ \\
\hline \multirow[t]{5}{*}{ Fair operating practices $\mathrm{A}_{24}$} & Promoting social responsibility in the value chain & \multirow{3}{*}{$\begin{array}{l}\text { Promoting social responsibility in the value chain } \mathrm{A}_{241} \\
\text { Political responsibility awareness } \mathrm{A}_{242}\end{array}$} \\
\hline & Anti-corruption & \\
\hline & Responsible political involvement & \\
\hline & Fair competition & Fair competition $\mathrm{A}_{243}$ \\
\hline & Respect for property rights & Respect for property rights $A_{244}$ \\
\hline \multirow[t]{7}{*}{ Consumer issues $\mathrm{A}_{31}$} & Protecting consumers' health and safety & \multirow[t]{3}{*}{ Fundamental rights of consumers $\mathrm{A}_{311}$} \\
\hline & Consumer data protection and privacy & \\
\hline & Access to essential services & \\
\hline & $\begin{array}{l}\text { Consumer service, support, and complaint and } \\
\text { dispute resolution }\end{array}$ & \multirow[t]{2}{*}{ Handling of disputes $\mathrm{A}_{312}$} \\
\hline & $\begin{array}{l}\text { Fair marketing, factual and unbiased information } \\
\text { and fair contractual practices }\end{array}$ & \\
\hline & Education and awareness & \multirow{2}{*}{ Education and awareness $\mathrm{A}_{313}$} \\
\hline & Sustainable consumption & \\
\hline \multirow{7}{*}{$\begin{array}{l}\text { Community involvement and } \\
\text { development } \mathrm{A}_{32}\end{array}$} & Community involvement & \multirow{4}{*}{$\begin{array}{l}\text { Community involvement } A_{321} \\
\text { Community environment } A_{322}\end{array}$} \\
\hline & Wealth and income creation & \\
\hline & Education and culture & \\
\hline & Health & \\
\hline & Employment creation and skills development & \multirow[t]{3}{*}{ Technology development $\mathrm{A}_{323}$} \\
\hline & Technology development and access & \\
\hline & Social investment & \\
\hline
\end{tabular}

Source: ISO 26000 Guidance on Social Responsibility.

Analytic Hierarchy Process (AHP) to evaluate the social responsibility risk assessment index. Five experts in the field of tourism investment risks were invited to score the importance (1-9) of each value dimension.

According to the judgment matrix of the impact degree of projects selection, project implementation and project follow-up management, as proposed in the assessment, the maximum eigenvalue $\lambda_{\max }$ equals 3.0120, and the weight on the reconstructed social responsibility risk assessment is 1.0 , the Consistency Ratio $(C R)=0.0115<0.1$. The normalized weight vectors corresponding to the maximum eigenvalues are presented in Table 6. From the weight vector column, it can be seen that the weight of project selection on reshaping the social responsibility risk assessment is $47.93 \%$, showing that project selection is the dominant factor of the social responsibility risk. Project follow-up management accounts for $30.68 \%$ and project implementation for $21.39 \%$, both playing considerable roles, between which project follow-up management has a stronger influence on the social responsibility risk of investment project.
Table 6 Stratified target judgment matrix in decision-making target

\begin{tabular}{lcccc}
\hline Reshaping risk indexes & $\mathbf{A}_{1}$ & $\mathbf{A}_{2}$ & $\mathbf{A}_{3}$ & $\begin{array}{c}\text { Weight } \\
\text { vector } \boldsymbol{W}\end{array}$ \\
\hline $\begin{array}{l}\text { Project selection } \mathrm{A}_{1} \\
\text { Project implementation } \mathrm{A}_{2}\end{array}$ & 1 & $5 / 2$ & $7 / 5$ & 0.4793 \\
$\begin{array}{l}\text { Project follow-up } \\
\text { management } \mathrm{A}_{3}\end{array}$ & $5 / 7$ & $9 / 7$ & 1 & 0.3068 \\
& & & & \\
& $\lambda_{\max }=3.0120, \mathrm{CR}=0.0115<0.1$ & \\
Weight on the overall target 1.0 & & \\
\hline
\end{tabular}

CR, consistency ratio.

\subsubsection{Weight measurement and consistency test of stratified target indexes}

Based on the assessment constructed above, weight measurement and consistency of the stratified targets in the alternative plan are tested respectively. Weight of each index in the stratified target is calculated and the consistency is tested. (1) Project selection $A_{1}$. 
According to the judgement matrix, the maximum eigenvalue is 3.010, and its weight on the reconstructed social responsibility risk assessment is 0.4793. (2) Project implementation $\mathrm{A}_{2}$. According to the judgement matrix, the maximum eigenvalue is 4.0554 , and the weight is 0.2139 . (3) Project follow-up management $\mathrm{A}_{3}$. According to the judgement matrix, the maximum eigenvalue is 2.0000 , and the weight is 0.3068 . Three stratified target judgment matrices and the normalized weight vector corresponding to the maximum eigenvalue are presented in Table 7.

\subsubsection{Weight measurement and consistency test of indexes in the alternative plan}

The reconstructed assessment of the social responsibility risk of the $\mathrm{B} \& \mathrm{R}$ large-scale tourism investment project abroad includes a total of 21 three-level value dimensions, and the corresponding index judgment matrix is shown in Table 8. In this paper, the maximum eigenvalue vector is calculated by integral method.

(1) Normalization of column elements in the judgment matrix. The general term of elements is $\tilde{h}_{i j}=\frac{h_{i j}}{\sum_{1}^{n} h_{i j}}(i, j=1,2, \cdots, n)$.

(2) Sum of rows in the judgment matrix $\tilde{w}_{i}=\sum_{1}^{n} \tilde{h}_{i j}(i, j=1,2, \cdots, n)$.

(3) Normalizing the vector $\tilde{w}_{i} \cdot w_{i}=\frac{\tilde{w}_{i}}{\sum_{1}^{n} \tilde{w}_{j}}(i, j=1,2, \cdots, n) . w=$ $\left(w_{1}, w_{2}, \ldots, w_{n}\right)^{T}$, the approximate solution of all eigenvectors.

(4) The maximum eigenvalue of the judgment matrix:

$\lambda_{\max }=\sum_{1}^{n} \frac{(H w)_{i}}{n w_{i}}$.

\section{RECONSTRUCTING AND POSITIONING THE WEIGHT DISTRIBUTION OF SOCIAL RESPONSIBILITY RISK ASSESSMENT FOR THE BELT AND ROAD LARGE-SCALE TOURISM INVESTMENT PROJECTS ABROAD}

The final weight distribution of social responsibility risk assessment for the large-scale tourism investment projects abroad is shown in Figure 1. The weights of the stratified targets (project selection $A_{1}$, project implementation $\mathrm{A}_{2}$ and project follow-up management $\mathrm{A}_{3}$ ) on the decision-making target (social responsibility risk assessment for investment projects) are $0.4793,0.2139$ and 0.3068 respectively. The weights of the sub-layers in the stratified targets are indicated as follows: international collaborative development 0.1696 , host domestic political environment 0.1535 , host geographic political environment 0.1562 , human rights 0.0513 , labor practice 0.0498 , environment 0.0554 , fair operation practice 0.0574 , consumer issues 0.1534 , community involvement and development 0.1534 . In the alternative plan, the dominant indexes are listed in turn as follows: the index of vulnerable group, a sub-layer to human rights, accounts for 0.068 , labor organization, sub-layer to labor practice, 0.0193, ecological restoration to the environmental 0.0161, fair operation practice to respect for property rights 0.0163 , dispute handling to consumer issues 0.0727 , and community environment to community participation and development 0.0610 , thus it can be seen that the top 10 dominant indexes in the third level are: dispute handling 0.0727 , community environment 0.0610 , education and awareness 0.0529 , community involvement 0.0499 , skills and technology 0.0426 , trade union 0.0193 , vulnerable groups 0.0168 , respect for property rights 0.0163 , ecological restoration 0.0160 and working conditions 0.0156 . Since the second-level indicators

Table 7 Stratified target judgment matrices

\begin{tabular}{|c|c|c|c|c|c|c|c|c|c|c|c|c|c|c|}
\hline$A_{1}$ & $A_{11}$ & $\mathbf{A}_{12}$ & $\mathbf{A}_{13}$ & $W$ & $\mathbf{A}_{2}$ & $A_{21}$ & $\mathbf{A}_{22}$ & $\mathbf{A}_{23}$ & $\mathrm{~A}_{24}$ & $W$ & $\mathrm{~A}_{3}$ & $\mathbf{A}_{31}$ & $\mathbf{A}_{32}$ & $W$ \\
\hline$A_{11}$ & 1 & 1 & $6 / 5$ & 0.3539 & $\mathrm{~A}_{21}$ & 1 & $4 / 5$ & $8 / 9$ & $6 / 5$ & 0.2399 & $\mathrm{~A}_{31}$ & 1 & 1 & 0.5 \\
\hline$A_{12}^{11}$ & 1 & 1 & $8 / 9$ & 0.3202 & $\mathrm{~A}_{22}^{21}$ & $5 / 4$ & 1 & $7 / 9$ & $7 / 9$ & 0.2327 & $\mathrm{~A}_{32}^{31}$ & 1 & 1 & 0.5 \\
\hline$A_{13}$ & $5 / 6$ & $9 / 8$ & 1 & 0.3259 & $\mathrm{~A}_{23}$ & $9 / 8$ & $9 / 7$ & 1 & $4 / 5$ & 0.2589 & - & - & - & - \\
\hline${ }_{-13}^{13}$ & - & - & - & - & $\mathrm{A}_{24}^{23}$ & $5 / 6$ & $9 / 7$ & $5 / 4$ & 1 & 0.2685 & - & - & - & - \\
\hline & \multicolumn{5}{|c|}{$\begin{array}{l}\quad \lambda_{\max }=3.010, \mathrm{CR}=0.0096<0.1 \\
\text { Weight on the overall target } 0.4793\end{array}$} & \multicolumn{5}{|c|}{$\begin{array}{c}\quad \lambda_{\max }=4.0554, \mathrm{CR}=0.0208<0.1 \\
\text { Weight on the overall target } 0.2139\end{array}$} & \multicolumn{4}{|c|}{$\begin{array}{l}\quad \lambda_{\max }=2.000, \mathrm{CR}=0.0000<0.1 \\
\text { Weight on the overall target } 0.3068\end{array}$} \\
\hline
\end{tabular}

CR, consistency ratio.

Table 8 Judgment matrices of targets in the alternative plan

\begin{tabular}{|c|c|c|c|c|c|c|c|c|c|c|c|c|c|c|c|c|}
\hline$A_{21}$ & $A_{211}$ & $A_{212}$ & $A_{213}$ & $A_{214}$ & $W$ & $\mathbf{A}_{22}$ & $A_{221}$ & $A_{222}$ & $A_{223}$ & $W$ & $\mathbf{A}_{23}$ & $A_{231}$ & $A_{232}$ & $\mathbf{A}_{233}$ & $\mathbf{A}_{234}$ & $W$ \\
\hline $\mathrm{A}_{211}$ & 1 & $5 / 6$ & $9 / 8$ & $5 / 4$ & 0.2554 & $\mathrm{~A}_{221}$ & 1 & $6 / 5$ & $4 / 3$ & 0.3874 & $\mathrm{~A}_{231}$ & 1 & $4 / 5$ & $6 / 5$ & $3 / 4$ & 0.2281 \\
\hline $\mathrm{A}_{212}$ & $6 / 5$ & 1 & $1 / 3$ & $7 / 5$ & 0.2124 & $\mathrm{~A}_{222}$ & $5 / 6$ & 1 & $8 / 9$ & 0.3130 & $\mathrm{~A}_{232}$ & $5 / 4$ & 1 & $7 / 5$ & $8 / 9$ & 0.2765 \\
\hline$A_{213}$ & $8 / 9$ & 3 & 1 & $6 / 5$ & 0.3283 & $\mathrm{~A}_{223}$ & $3 / 4$ & $9 / 8$ & 1 & 0.2997 & $\mathrm{~A}_{233}$ & $5 / 6$ & $5 / 7$ & 1 & $4 / 5$ & 0.2057 \\
\hline \multirow[t]{2}{*}{$\mathrm{A}_{214}^{213}$} & $4 / 5$ & $5 / 7$ & $5 / 6$ & 1 & 0.2039 & - & - & - & - & - & $\mathrm{A}_{234}^{233}$ & $4 / 3$ & $9 / 8$ & $5 / 4$ & 1 & 0.2897 \\
\hline & \multicolumn{5}{|c|}{$\begin{array}{l}\quad \lambda_{\max }=4.2262, \mathrm{CR}=0.0847<0.1 \\
\text { Weight on the overall target } 0.0513\end{array}$} & \multicolumn{6}{|c|}{$\begin{array}{c}\quad \lambda_{\max }=3.0055, \mathrm{CR}=0.0053<0.1 \\
\text { Weight on the overall target } 0.0498\end{array}$} & \multicolumn{5}{|c|}{$\begin{array}{c}\quad \lambda_{\max }=4.0076, \mathrm{CR}=0.0029<0.1 \\
\text { Weight on the overall target } 0.0554\end{array}$} \\
\hline
\end{tabular}

\begin{tabular}{|c|c|c|c|c|c|c|c|c|c|c|c|c|c|c|c|}
\hline$A_{24}$ & $A_{241}$ & $A_{242}$ & $A_{243}$ & $\mathbf{A}_{244}$ & $W$ & $A_{31}$ & $A_{311}$ & $A_{312}$ & $A_{313}$ & $W$ & $A_{32}$ & $A_{321}$ & $A_{322}$ & $A_{323}$ & $W$ \\
\hline$A_{241}$ & 1 & $5 / 4$ & 1 & $7 / 9$ & 0.2470 & $A_{311}$ & 1 & $1 / 2$ & $2 / 5$ & 0.1809 & $\mathrm{~A}_{321}$ & 1 & $4 / 5$ & $6 / 5$ & 0.3253 \\
\hline $\mathrm{A}_{242}$ & $4 / 5$ & 1 & $7 / 9$ & $7 / 8$ & 0.2136 & $\mathrm{~A}_{312}$ & $2 / 1$ & 1 & $9 / 5$ & 0.4740 & $\mathrm{~A}_{322}$ & $5 / 4$ & 1 & $7 / 5$ & 0.3974 \\
\hline $\mathrm{A}_{243}$ & 1 & $9 / 7$ & 1 & $6 / 7$ & 0.2548 & $\mathrm{~A}_{313}$ & $5 / 2$ & $5 / 9$ & 1 & 0.3451 & $\mathrm{~A}_{323}$ & $5 / 6$ & $5 / 7$ & 1 & 0.2774 \\
\hline \multirow[t]{2}{*}{$\mathrm{A}_{244}^{243}$} & $9 / 7$ & $8 / 7$ & $7 / 6$ & 1 & 0.2846 & - & - & - & - & - & - & - & - & - & - \\
\hline & \multicolumn{5}{|c|}{$\begin{array}{l}\quad \lambda_{\max }=4.0125, \mathrm{CR}=0.0047<0.1 \\
\text { Weight on the overall target } 0.0574\end{array}$} & \multicolumn{5}{|c|}{$\begin{array}{l}\quad \lambda_{\max }=3.0735, \mathrm{CR}=0.0707<0.1 \\
\text { Weight on the overall target } 0.1534\end{array}$} & \multicolumn{5}{|c|}{$\begin{array}{l}\quad \lambda_{\max }=3.0005, \mathrm{CR}=0.0005<0.1 \\
\text { Weight on the overall target } 0.1534\end{array}$} \\
\hline
\end{tabular}




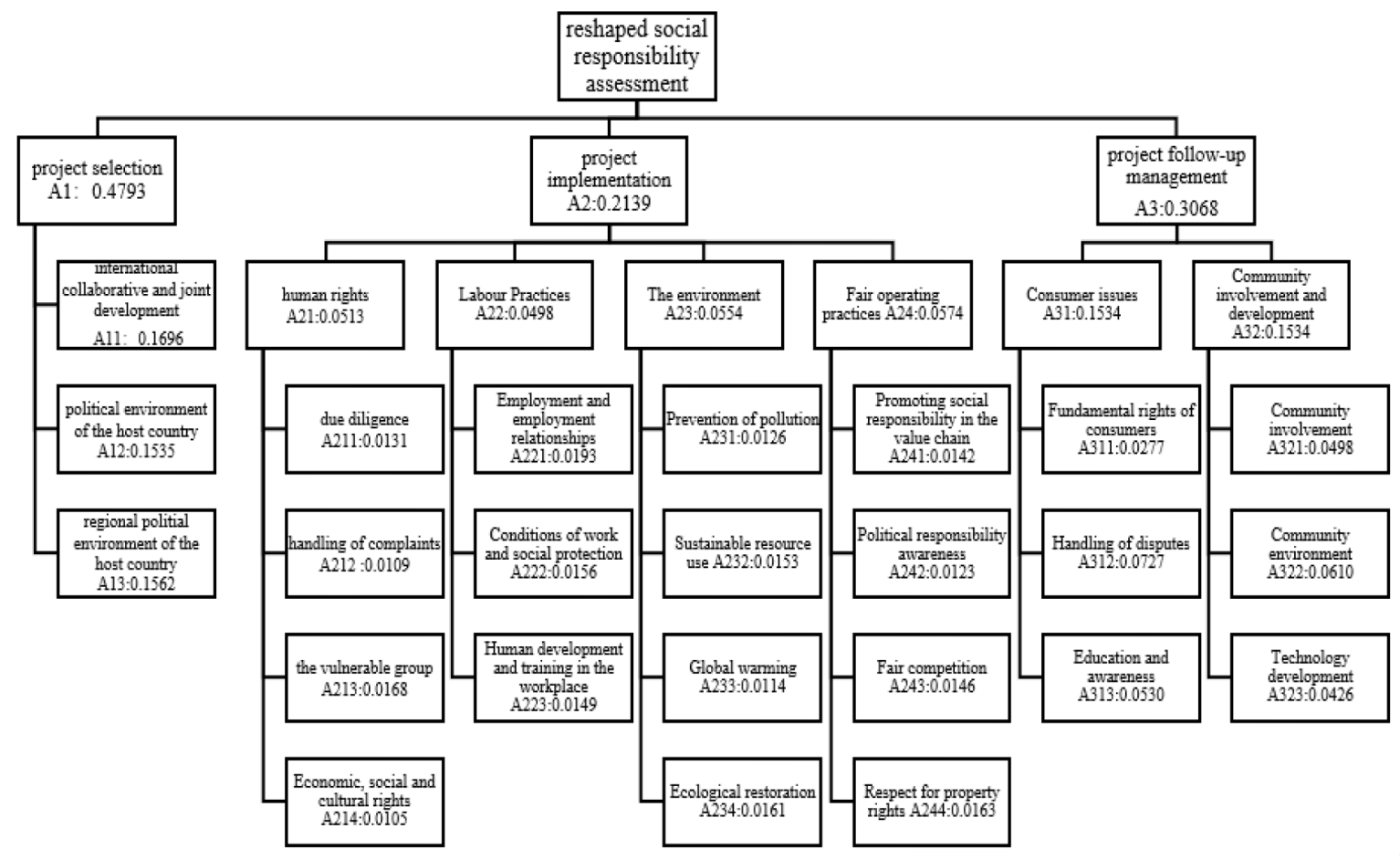

Figure 1 Weight distribution in the reconstructed social responsibility risk assessment for the Belt and Road large-scale tourism investment project abroad.

$\left(A_{11}, A_{12}\right.$, and $\left.A_{13}\right)$ are not sub-divided, project management after the completing the project bears significantly high social responsibility risks, far higher than the risks during the project construction. Therefore, under the premise of cautious selection of projects, more focus should be laid on preventing the social responsibility risks in the follow-up operation and management of the $B \& R$ large-scale tourism investment projects abroad.

\section{CONCLUSION AND DISCUSSION}

Traditional economic risks are no longer the dominant risks for China's large-scale tourism investment abroad. Instead, social responsibility risks, such as labor conflict, environmental factors, cultural risks, community involvement and development, and educational awareness have taken the place in the $B \& R$ largescale tourism investment projects abroad. If corresponding social responsibility risks cannot be effectively handled, safety of China's $\mathrm{B} \& \mathrm{R}$ large-scale tourism investment projects abroad may be threatened. With the promulgation and implementation of ISO 26000, social responsibility standards have become a tool for some countries to carry out green barriers and it has been an irreversible international trend for enterprises to take social responsibility with economic globalization. Therefore, it is particularly urgent and significant to study the social responsibility risk of China's B\&R large-scale tourism investment projects abroad based on ISO 26000. It is also an urgent need to establish a forward-looking and scientific social responsibility risk assessment mechanism in the current practice of social responsibility risk management. The theoretical contribution of this paper is to propose the assessment mechanism of social responsibility risks in China's large-scale tourism investment, further stressing the importance of management in not only project implementation, but also in project selection and project follow-up.
Based on the six core subjects, namely human rights, labor practices, the environment, fair operating practices, the consumers and community involvement and development, and 35 issues listed in ISO 26000, this paper reconstructs a social responsibility risk assessment for the B\&R large-scale tourism investment projects abroad and positions each index according to their weight on the principle of being scientific and systematic, complete and comprehensive, measurable, comparable, sustainable and forward-looking (Xiao, 2016) [47]. The assessment consists of three first-level value dimensions, namely project selection, project implementation and project follow-up management; nine second-level value dimensions including international cooperation and joint development, domestic political environment of host country, regional political environment of host country, etc.; and 21 third-level value dimensions including indicators of due diligence, complaints processing, vulnerable groups, and economic, social and cultural rights.

(1) It is an important subject to quantify the social responsibility risks, to reconstruct the comprehensive evaluation system and thus to identify each evaluation index according to ISO 26000. Social responsibility risk assessment has become an essential part to select, assess and reduce social responsibility risks in the $\mathrm{B} \& \mathrm{R}$ large-scale tourism investment projects abroad.

(2) According to the reconstructed social responsibility risk assessment, the management and supervision of social responsibility risks of project investment should be strengthened. In the whole process of large tourism investment project management, the social responsibility risk of project selection is increasingly highlighted. In the first-level index of project selection $\left(\mathrm{A}_{1}\right)$, the importance of international cooperative development, domestic political environment of the host country, and regional political environment of the host country should be emphasized so as to strengthen the management of social responsibility. In the first-level index of project implementation $\left(A_{2}\right)$, social responsibility is to be 
fulfilled from four aspects: human rights, labor practice, the environment and fair operating practices; while in the third-level index of project follow-up management $\left(\mathrm{A}_{3}\right)$, social responsibility is to be practiced from the perspectives of consumer issues and community involvement and development. Therefore, based on the ISO 26000 international standard, conducting whole-process management in B\&R large-scale tourism investment projects abroad is of great significance to reduce social responsibility risks and facilitate reinvestment so as to realize the sustainable development of the B\&R large-scale tourism investment projects abroad.

There are some limitations in this paper. Firstly, instead of adopting a comprehensive method to elaborate the research, we use only the method of AHP to construct the assessment mechanism of social responsibilities risks. Secondly, it is necessary to further verify the validity of the reconstructed assessment in corresponding cases, which we fail to do due to lack of space. The next step is to further verify the scientificity and rationality of the comprehensive assessment of social responsibility risks constructed in this paper.

\section{CONFLICTS OF INTEREST}

The authors declare they have no conflicts of interest.

\section{AUTHORS' CONTRIBUTION}

In writing this paper, based on the International Organization for Standardization (ISO) 26000 Guidance on Social Responsibility, CL proposes the key points of social responsibility risk assessment for the Belt and Road large-scale tourism investment project abroad. With the method of analytic hierarchy process, XL positions and sorts the indicators of social responsibility risk assessment, and reconstructs the assessment for the Belt and Road large-scale tourism investment project abroad.

\section{ABOUT THE AUTHORS}

Chen Lv (1981-), male, born in Jining, Shandong province. Doctor of Economics, professor of Taishan University and post-doctor of China Tourism Academy. Main research interests: industrial upgrading, industrial policy and tourism investment risk, etc.

Xiaoyan Li (1988-), female, born in Huize, Yunnan Province. Master of Arts, associate professor of Taishan University. Research interests: tourism safety and tourism culture.

\section{ACKNOWLEDGMENT}

As a phased achievement, this paper owes to the support of the Talent Introduction and Education Project of Youth Innovation Team in Colleges and Universities of Shandong Province (Tourism Investment Risk and Management Innovation Team) (95), Social science planning project of Shandong Province (Digital Shandong special project) (20CSDJ62) and China Postdoctoral Science Foundation Project (2017M620958).

\section{REFERENCES}

[1] Lv C, Lin HC. Dynamic monitoring and decision making system for large-scale foreign investment projects. Reform 2016;5:89100 (in Chinese).

[2] Ghosh S, Jintanapakanont J. Identifying and assessing the critical risk factors in an underground rail project in Thailand: a factor analysis approach. Int J Project Manage 2004;22:633-43.

[3] Huseby AB, Skogen S. Dynamic risk analysis: the Dynrisk concept. Int J Project Manage 1992;10:160-4.

[4] Jiang W, Deng L, Chen L, Wu J, Li J. Risk assessment and validation of flood disaster based on fuzzy mathematics. Prog Nat Sci 2009;19:1419-25.

[5] Irene Hall H, Ramana Dhara V, Price-Green PA, Kaye WE. Surveillance for emergency events involving hazardous substances - United States, 1990-1992. Surveill Summar 1994;43:1-6.

[6] Malone TW, Crowston K, Lee J, Pentland B, Dellarocas C, Wyner $\mathrm{G}$, et al. Tools for inventing organizations: toward a handbook for organizational processes. Manag Sci 1999;45:296-454.

[7] Knight K, Fayek AR. Use of fuzzy logic for predicting design cost overruns on building project. J Constr Eng Manage 2002;128:503-12.

[8] Lee S, Daniel WH. Predictive tool for estimating accident risk. J Constr Eng Manage 2003;129:431-6.

[9] Lin CT, Chen YT. Bid/no-bid:decision-making - a fuzzy linguistic approach. Int J Project Manage 2004;22:585-93.

[10] Sadiq R, Husain T. A fuzzy-based methodology for an aggregative environmental risk assessment: a case study of drilling waste. Environ Model Softw 2005;20:33-46.

[11] Motawa IA, Anumba CJ, El-Hamalawi A. A fuzzy system for evaluating the risk of change in construction projects. Adv Eng Softw 2006;37:583-91.

[12] Su JJ, Wang XM. The spatial-temporal evolution characteristics and driving factors of China's tourism investment structure benefit. Geogr Geo-inform Sci 2020;36:117-24.

[13] Jia K. Government public investment, social investment and economic and social development. J Southwest Minzu Univ (Human Soc Sci) 2010;31:138-41 (in Chinese).

[14] Han PC, Xue L, Wang WJ. Corporate innovation, social responsibility and corporate value - a case study of small and medium-sized enterprises. Forum Sci Technol China 2020;93-9 (in Chinese).

[15] Zhou SP, Ren JZ. Corporate social responsibility management theory and practice in China. J Chinese Acad Govern 2010;66: 38-41 (in Chinese).

[16] Huang XJ, Tang LX. Political association, equity financing and the change of the raised funds. Soft Sci 2012;26:123-6 (in Chinese).

[17] Meng B, Li F, Yang Y. Research on the evaluation of corporate social responsibility in transportation industry based on circular correction. Sci Res Manage 2020;41:174-84 (in Chinese).

[18] Zheng YX. Don't be blind in energy conservation and emission reduction. Study Pract 2011;24-32 (in Chinese).

[19] Lin ZM. An imperative trend of the transformation and upgrading of the Chinese economy. Econ Rev J 2014;17-22 (in Chinese).

[20] Wang YN, Li ZJ, Zhang BR. The influencing factors and mechanism of social responsibility of transnational corporations under “One Belt And One Road". Econ Probl 2020;82-90 (in Chinese).

[21] Cong ShH, Zhou W, Yu N. Formulating indicators for the evaluation of public expenditure performance. Finance Trade Econ $2005 ; 37-41+97$. 
[22] Hong XJ, Li JC. A review of the polarization measurement method and the polarization of Chinese residents' income. Econ Res J 2007;139-53 (in Chinese).

[23] $\mathrm{Hu}$ B, Shen L, Gong J. The market value effect of social responsibility of China's listed tourism enterprises: from the perspective of marketing strategy analysis. Tour Tribune 2006;35-42 (in Chinese).

[24] Zhou JQ, Wang TS. Foreign direct investment, economic growth and CO2 emissions. J Beijing Inst Technol (Soc Sci Ed) 2014;30-8 (in Chinese).

[25] Feng Z, Zhang SD. Research on the dynamic evaluation of risk index and risk coefficient of agricultural high-tech project investment. Sci Technol Manage Res 2010;14:88-90 (in Chinese).

[26] Li L. Design of performance evaluation index of public works project based on balanced Scorecard method. Soc Sci 2007;16870 (in Chinese).

[27] Sun H, Edziah BK, Sun C, Kporsu AK. Institutional quality, green innovation and energy efficiency. Energy Policy 2019;135: 111002.

[28] Sun H, Mohsin M, Alharthi M, Abbas Q. Measuring environmental sustainability performance of South Asia. J Clean Prod 2019;251:119519.

[29] Yang Zh, Chen J. Innovation and governance of corporate social responsibility in the digital and intelligent era. J Shanghai Univ of Finance Econ 2020;22:33-51 (in Chinese).

[30] Lv WQ, Ge XF. Social capital theory and community tourism operators' social responsibility. Thinking 2020;46:156-164 (in Chinese).

[31] Zhang ShB, Yang QB, Zhang YW. The risk management of infrastructure investment projects. Int Project Contracting and Labour Service 2016;74-75 (in Chinese).

[32] Li YW. A rational approach to the influence of TPP on China: opportunities, challenges and countermeasures. Contemporary Econ 2016;10-13 (in Chinese).

[33] $\mathrm{Pu}$ Y. Analysis of the risk factors of Chinese railway enterprises' foreign investment and countermeasures. Business 2015;160 (in Chinese).
[34] Yang HR, Pi JC. The analysis of corporate social responsibility in the vertical market structure. Mod Econ Sci 2019;41:97-107 (in Chinese).

[35] Huang ZhX. For the hundreds-arces demolition project. People's Political Scene 2011;48 (in Chinese).

[36] Wang LF. The human rights policy of China's overseas investment enterprises. Human Rights 2013;37-40 (in Chinese).

[37] Feng F. A brief analysis of consumer group litigation--On the protection of consumers in anti unfair competition law. Contemporary Manager 2005;236-237 (in Chinese).

[38] Wang B, Zhou X, Yang Ch. On consumer problem and its harmfulness. Soc Sci Yunan 2005;62-67 (in Chinese).

[39] He JW. Market demand and product quality strategy. Acad Res 1995;43-45 (in Chinese).

[40] Zhao XB. Deepen the enterprise environment research and improve the enterprise management level. Wuhan Univ J (Philosophy Soc Sci) 2005;437 (in Chinese).

[41] Jiang FX. Academic record of the track of reform and development. Jianghai Acad J 2009;20-21 (in Chinese).

[42] Zhang XQ. Interpretation of outdoor heat resource wells for water source heat pump system wells. Green building 2013;5:4142 (in Chinese).

[43] Drucker PF. Management: tasks, responsibilities, practices. Beijing: China Machine Press; 2007.

[44] Fabrizi M, Mallin C, Michelon G. The role of CEO's personal incentives in driving corporate social responsibility. J Business Ethics 2014;124:311-326.

[45] Li LQ. A theoretical and empirical study on corporate social responsibility evaluation. South China J Econ 2006;105-18.

[46] Zhang XT, Zheng YJ, Yue YS. Heterogeneity of the impact of host country's government behavior on Chinese enterprises' overseas investment decision-based on the perspective of enterprise size. Acad Forum 2014;37:30-36 (in Chinese).

[47] Xiao HJ. A study on the reform of corporate governance of public-policy-related state-owned enterprises. Reform of Econ Sys 2016;5-11 (in Chinese). 